\title{
Governo colonial, distância e espera nas minas e capitania de Goiás*
}

\author{
Fernando Lobo Lemes \\ Instituto Brasil de Ciência e Tecnologia, FIBRA \\ Anápolis, GO, Brasil \\ fernandolobolemes@gmail.com
}

\begin{abstract}
RESUMO
A temporalidade da espera associada aos intervalos impostos pelas distâncias geográficas à burocracia do governo colonial instala a vida dos habitantes de Goiás num ambiente transitório, constituído de eventos provisórios, onde os protagonistas devem fazer face às incertezas, enquanto esperam pelas decisões do rei de Portugal. Com a morte súbita do capitão-general João Manoel de Melo, a formação de um governo provisório aparece como estratégia das elites locais para controlar o tempo de espera e preencher o vazio de poder deixado pela ausência do governador. Neste cenário, os acontecimentos são percebidos como interaçôes de força, cujas tensôes podem transformar, ainda que transitoriamente, as relaçôes estabelecidas na hierarquia dos poderes do império.
\end{abstract}

Palavras-chave: império português; temporalidades; distância; espera; Goiás.

\section{ABSTRACT}

The waiting temporality associated with the intervals imposed by the geographic distances to the colonial government bureaucracy installed the lives of inhabitants of Goiás in a transitory environment, consisting of provisional events, where the protagonists must cope with uncertainties, while they waited for the King of Portugal's decisions. With the sudden death of captain-general João Manoel de Melo, the formation of an interim Government appeared as a strategy of local elites that sought to control the waiting time and fill the power vacuum left by the absence of the Governor. In this scenario, the events were perceived as interactions of forces, the tensions of which could temporarily transform the established relationships in the Empire's hierarchy.

Keywords: Portuguese empire; temporalities; distance; waiting time; Goiás.

\footnotetext{
* Agradeço ao professor Laurent Vidal a inspiração e a possibilidade de uma reflexáo partilhada a propósito de uma sociologia da espera na história de Goiás e do Brasil colonial.

Artigo recebido em 15 de fevereiro de 2012 e aceito em 20 de junho de 2012.
} 


\section{Introdução}

Nas minas e capitania de Goiás uma barreira quase intransponível funcionava como obstáculo à plena e imediata execução das determinaçóes do rei de Portugal: a distância que separava Lisboa de Vila Boa. Ali, as grandes extensóes geográficas, somadas aos limites tecnológicos da época, definiam a cadência das tropas que atravessavam o sertão e das fragatas levadas pelos ventos que cruzavam o Atlântico. Assim, a circulação dos vassalos do rei, das informaçôes que formatavam o governo imperial, a tramitaçâo das correspondências administrativas e, por consequência, a burocracia do império, também padeciam dos efeitos inexoráveis das distâncias e dos níveis tecnológicos disponíveis.

De um ponto de vista mais vasto, o tema da distância é muito comum nas análises dos problemas associados ao sistema colonial e à administração do império português. Não raro é invocado na historiografia brasileira como fator de grande relevância para a compreensão das relações de poder no período colonial. ${ }^{1}$ Por outro lado, a conhecida metáfora do padre Antônio Vieira sobre os paradoxos que envolviam a complexa equação entre o poder régio e as distâncias que marcavam o vasto império português, ${ }^{2}$ desde a Ásia até a América, remete ao século XVII a notória preocupaçáo com o tema. ${ }^{3}$

Neste sentido, se o objeto que norteava a pena de Vieira era essencialmente a corrupçáo incrustada na vida política do império, a metáfora do sol e da sombra - enquanto referência à distância geográfica do monarca português com relação às regiôes de conquista - serviu de inspiração, três séculos mais tarde, para o importante livro da professora Laura de Mello e Souza, que analisa problemas cotidianos comuns nos relatos sobre a administração ultramarina ao longo do século XVIII. ${ }^{4}$ Assim, desde a corrupção denunciada por Vieira aos problemas administrativos anunciados no estudo de Laura de Mello e Souza, a distância é considerada um fator de grande relevância para a compreensão das relaçóes de

\footnotetext{
${ }^{1}$ Ver, por exemplo, obras e artigos importantes que tratam direta ou indiretamente sobre o tema, tais como: SOUZA, Laura de Mello e. O sol e sombra: política e administração na América portuguesa do século XVIII. São Paulo: Companhia das Letras, 2006; FRAGOSO, João; GOUVÊA, Maria de Fátima Silva (Org.). Na trama das redes. Política e negócios no império português. Séculos XVI-XVIII. Rio de Janeiro: Civilização Brasileira, 2010; SOUZA, Laura de Mello; FURTADO, Júnia Ferreira; BICALHO, Maria Fernanda (Org.). O governo dos povos: relaçóes de poder no mundo ibérico da Época Moderna. São Paulo: Alameda, 2009 e, ainda, BICALHO, Maria Fernanda; FERLINI, Vera Lúcia Amaral (Org.). Modos de governar: ideias e práticas políticas no Império português, séculos XVI a XIX. São Paulo: Alameda, 2005; RAMINELLI, Ronald José. Viagens ultramarinas: monarcas, vassalos e governo à distância. São Paulo: Alameda, 2008; ARAÚJO, Emanuel. Tão vasto, tão ermo, tão longe: o sertão e o sertanejo nos sertôes coloniais. In: PRIORE, Mary Lucy del (Org.). Revisáo do Paraíso: os brasileiros e o Estado em 500 anos de história. Rio de Janeiro: Campus, 2000; DEAN, Warren. The frontier in Brazil. In: Frontiers in comparative perspectives. Washington, DC: The Woodrow Wilson Center, 1990.

${ }^{2}$ FURTADO, Júnia Ferreira. O sol e a sombra — Política e administração na América portuguesa do século XVIII. Resenha. Almanack Braziliense, n. 5, p. 137-139, 2007.

${ }^{3}$ Repleto das oposiçóes e antíteses características do barroco, o discurso do padre Antônio Vieira é marcado pela tese da impossibilidade de um governo colonial bom e justo. "É isto", diz ele, "é o que se vê na Ásia, e na América, e nas Índias Orientais, onde nasce o sol, e nas Ocidentais, onde se póe. Não pode haver semelhança mais própria. A sombra, quando o sol está no zênite, é muito pequenina, e toda se vos mete debaixo dos pés; mas quando o sol está no oriente, ou no ocaso, essa mesma sombra se estende tão imensamente que mal cabe dentro dos horizontes. Assim nem mais nem menos os que pretendem e alcançam os governos ultramarinos. Lá onde o sol está no zênite, não só se metem estas sombras debaixo dos pés do príncipe, senão também dos seus ministros. Mas, quando chegam àquelas Índias, onde nasce o sol, ou a estas, onde se póe, crescem tanto as mesmas sombras que excedem muito a medida dos mesmos reis, de que são imagens.” Em seguida, comparando o império português com o romano, prossegue: "De Roma a Jerusalém ainda tinham algum vigor os respeitos de Cesar: Si hunc dimitis... Mas de Lisboa à Índia e ao Brasil com todo o mar oceano em meio? A fé, a obrigação, a obediência, o respeito, tudo se esfria, tudo se mareia, tudo referve. Vendo-se tão longe de quem as manda, como lá podem o que querem, não se contentam com o querer o que podem. Levam os poderes de imagens e tomam onipotências de Césares..." e estes poderes ilimitados são instrumentos ordinários para o roubo e a violência. PALACIN, Luís. Vieira e a visão trágica do barroco: quatro estudos sobre a consciência possível. São Paulo: Hucitec, 1986. p. 22.

${ }^{4}$ SOUZA, Laura de Mello e. O sol e sombra, op. cit.
} 
poder no império português. Não é novidade, portanto, o tema da distância na história nem, tampouco, na historiografia do império português.

Em Goiás não é diferente. De igual modo, a noção de distância também assume importância indiscutível para o estudo da história da região situada no coração da América portuguesa, durante o século XVIII. Contudo, nos limites do presente estudo, não se trata de buscar nas referências ao tempo e à distância os argumentos norteadores de um discurso historiográfico que sempre reforçou a ideia do isolamento de Goiás no contexto mais amplo do império. Nem, tampouco, de apresentar ou relatar as dificuldades impostas pelas distâncias à plena execução dos projetos coloniais lusos na região central da América. Nosso objetivo é também demonstrar que as inúmeras dificuldades interpostas ao governo colonial não paralisaram as iniciativas da Coroa, nem tampouco detiveram os espíritos arrojados dos homens que se embrenhavam pelos sertóes da América. Muito pelo contrário, o desejo de vencer as barreiras estimulava empreendimentos e servia de combustível para a execução dos projetos de Lisboa. Além disso, nossa intenção está associada à análise de outro aspecto proporcionado pelas contingências apresentadas pelas enormes distâncias geográficas no interior do império: a existência de intervalos de espera que condicionavam a gestão do governo colonial nas minas de Goiás. Ao discorrer, finalmente, sobre o caso envolvendo a morte não anunciada do governador, não temos a pretensão de apresentá-lo como acontecimento exemplar para o estudo da noção de distância no império português. Antes, pretendemos observá-lo como episódio que desnuda a experiência dos protagonistas num momento de exceção, de ruptura momentânea com as normas, revelando a consciência dos atores num momento intermediário de transição, envolvido pelo manto e pelas condiçốes ditadas pela temporalidade da espera nas minas e capitania de Goiás.

\section{De Lisboa a Vila Boa: entre o oceano Atlântico e as minas de ouro do sertão}

Assim, em Goiás, do ponto de vista prático, uma espécie de tirania da distância ${ }^{5}$ condicionava a existência dos homens e das coisas, definindo o ritmo da vida ao longo de todo o século XVIII. Neste aspecto, nem mesmo os planos arquitetados em Lisboa estavam imunes à rebeldia do mar e aos caprichos dos caminhos, do clima e das intempéries do sertão. De fato, nas três dimensôes da geografia do império percebidas a partir da América — o reino de Portugal, as cidades voltadas para o Atlântico e os espaços interiores dos sertóes —, as distâncias foram sempre decantadas como fator de dificuldade para a consecução dos projetos da monarquia.

Em Goiás, referências muito frequentes à distância do reino, dos longínquos portos da América portuguesa, das capitanias vizinhas e a grande extensão territorial da própria capitania estiveram presentes na pena das autoridades coloniais, denunciando seus reflexos nas mais diversas atividades administrativas.

Se considerarmos a tecnologia da época, o grau de dificuldade na transposição das rotas oceânicas e dos caminhos terrestres ou fluviais pode ser traduzido através de outra unidade de medida: o tempo.

\footnotetext{
${ }^{5} \mathrm{O}$ termo "tirania" (do grego túpavvos, líder ilegítimo), historicamente associado à Grécia Antiga, é uma forma de governo usada em situaçôes excepcionais, em alternativa à democracia. Nela o chefe governava com poder ilimitado, embora sem perder de vista que devia representar a vontade do povo. Hoje, entre as sociedades democráticas ocidentais, o termo tirania tem conotação negativa, já que remete a uma forma de governo náo respaldado pelo direito e pela lei, porém fortemente embasado na autoridade de um governante. Contudo, na acepção empregada neste artigo, para além das noçóes que denotam ideias como governo injusto e despotismo, severidade, opressão política e violência ou ingratidão, a concepção de tirania indica o poder que certas coisas exercem às vezes sobre o homem ou sobre suas atividades ou, ainda, sobre seus planos e projetos. Mais especificamente, o poder da distância, considerado no tempo e no espaço, sobre o exercício prático do governo colonial, com sede política e administrativa em Lisboa, em um território de conquista (neste caso, as minas e capitania de Goiás).
} 
A viagem empreendida pelo governador Álvaro José Xavier Botelho de Távora, o conde de São Miguel, pode nos oferecer um panorama a respeito da distância que separa Lisboa de Goiás. Como havia perdido a fragata que partiu no mês de julho, que lhe permitiria desembarcar diretamente no porto de Santos, Botelho de Távora partiu de Lisboa no dia 10 de agosto de 1754 em direção ao Rio de Janeiro. Após a travessia do Atlântico, chegou às margens do litoral pernambucano "com a cabeça tão perdida" que lhe era necessário "ou estar deytado ou andar encostado para não cahir!". ${ }^{6}$ Ali, permaneceu a bordo da embarcação devido à "inconstância da costa" e à "dificuldade da barra", a uma distância de cinco léguas do continente. Em seguida, navegou rumo ao sul onde, para alívio de suas náuseas, no dia 13 de outubro, após 64 dias de viagem, ancorou no porto da cidade do Rio de Janeiro.

No continente, os obstáculos para a travessia do sertão anunciavam um longo tempo de espera. Advertido sobre os riscos do período chuvoso, planejava sua partida às minas de Goiás para o mês de maio do ano seguinte. "Athé fevereiro", relata o conde de São Miguel, "são os rios perigozos de passar e os atoleyros invadiaveis, e athe mayo correm a vazantes, com ar tão maligno" que os moradores locais chamam a este período de "tempo da peste". Assim, permaneceu no Rio de Janeiro até o dia 17 de junho de 1755, quando partiu em direção a Goiás.

Adentrando o sertão, viajou durante quatorze dias até Vila Rica, em Minas Gerais, onde permaneceu por oito dias com o objetivo de comprar "cavallos capazes", por "náo os haver no Rio". Prosseguindo sua marcha, deixou Vila Rica em 8 de julho, alcançando Paracatu no dia 2 de agosto, após 25 dias de caminhada. Parada obrigatória para o descanso da tropa, aí se deteve por três dias. Finalmente, no dia 15 de agosto, foi recepcionado pelo entáo governador Marcos de Noronha no arraial de Meia Ponte, onde permaneceu por nove dias. Após quatro dias de percurso, atingiu a capital Vila Boa de Goiás em 28 de agosto de $1755 .^{8}$

Seu périplo, de Lisboa a Vila Boa, havia durado pouco mais de um ano. Se subtrairmos o período de oito meses na cidade do Rio de Janeiro, o conde de São Miguel permaneceu 64 dias sobre o mar e outros dois meses e onze dias nos caminhos do sertão. Assim, foram necessários cerca de quatro meses e meio de viagem para vencer a distância que separa Portugal de Goiás. Noutras circunstâncias, poderia ter poupado vinte dias dirigindo-se diretamente ao porto de Santos, caso não tivesse seguido via Pernambuco, o que teria reduzido o tempo de sua viagem para pouco menos de quatro meses.

Mas esta foi uma viagem relativamente rápida para os padróes da época. Marcos de Noronha, conde dos Arcos, primeiro governador de Goiás, precisou de 85 dias para completar o percurso entre o Rio de Janeiro e Vila Boa. De fato, o tempo médio calculado pelas autoridades coloniais para o transporte do quinto do ouro entre Goiás e o Rio de Janeiro era de três meses. ${ }^{9}$ Da mesma forma, os caminhos que ligavam Goiás à cidade de Salvador não fugiam aos mesmos padrôes de tempo e distância.

A conjugação entre longos percursos e a instabilidade climática ditava o compasso da mobilidade dos homens. Com pequenas variaçóes, o ritmo cíclico das estaçóes definia dois momentos distintos que condicionavam os deslocamentos humanos nas minas de Goiás. De acordo com o naturalista francês Provençal de Saint-Hilaire, "o ano se divide em Goiás em duas estaçôes distintas; a estação das chuvas que começa em setembro e aquela da seca que começa em abril". ${ }^{10}$ Ao período de chuvas, intenso durante os meses de dezembro e janeiro, segue-se o tempo da seca, mais intenso durante o inverno, entre

\footnotetext{
${ }^{6}$ Arquivo Histórico Ultramarino (AHU). Administração Central (ACL), Conselho Ultramarino (CU), Série 008, Cx. 11, Documento 671.

${ }^{7}$ Ibidem.

${ }^{8}$ Ibidem.

${ }^{9}$ Arquivo Histórico de Goiás (AHG). Cx. 1129, folha 165.

${ }^{10}$ Para uma descrição sobre o clima e a salubridade em Goiás na primeira metade do século XIX, ver SAINT-HILAIRE, Auguste de Provençal de. Voyage aux sources du Rio de S. Francisco et dans la province de Goyaz. Paris: Arthur Bertrand, 1847. t. I, p. 323.
} 
os meses de julho e agosto. O tempo das chuvas alterava consideravelmente as previsóes e os prazos para a travessia dos percursos. O barão de Mossâmedes, José de Almeida de Vasconcelos de Soveral e Carvalho, tendo chegado ao porto do Rio de Janeiro no dia primeiro de dezembro de 1771, adiou sua viagem a Vila Boa, onde assumiria o cargo de governador de Goiás, para o mês de abril alegando as "dificuldades com os rios" e a "malignidade das águas". ${ }^{11}$ Quando não se respeitava este ciclo natural das estaçóes, as viagens podiam ser interrompidas bruscamente sendo necessário abrigar-se num arraial por meses inteiros, à espera de melhor tempo para prosseguir a marcha. ${ }^{12}$

Quando se tratava do transporte de produtos comerciais, o tempo despendido na viagem podia se multiplicar. As difíceis condiçôes deixadas pela estação das águas impunham a necessidade de longas temporadas de espera e prolongados períodos de repouso para a recuperação dos animais, o que fazia com que as viagens se dilatassem por anos. ${ }^{13} \mathrm{Na}$ verdade, o desafio das distâncias nos sertôes pode ser comparado à magnitude da travessia do Atlântico: parecia mais cômoda, além de menos demorada, a viagem marítima entre Lisboa e o Rio de Janeiro, Santos, Bahia ou Pernambuco, que destes portos para o interior do continente.

\section{A conquista da distância: os avanços dos projetos de Lisboa na geografia das minas de Goiás}

Entretanto, tendo como pano de fundo a procura inexorável do ouro, as dificuldades não intimidavam a Coroa, nem detinham o espírito aventureiro dos homens que adentravam o sertão. Ao contrário, o desejo de vencer as barreiras ampliadas pelas distâncias estimulava as iniciativas e os projetos contemplados por Lisboa. Neste aspecto, as narrativas dos roteiros de viagens produziram descriçóes dos caminhos fluviais que interligavam como veias a vida dos sertôes. ${ }^{14}$ Além disso, as rotas terrestres também eram incessantemente exploradas. Em 1750, um projeto de grande envergadura, encabeçado por Francisco Tosi Colombina, propunha ao monarca a construçáo de um caminho interligando a cidade de São Paulo e a vila de Santos a Vila Boa de Goiás e, daí, até a vila de Cuiabá. ${ }^{15}$ Contra os argumentos que advogavam a impossibilidade da execuçáo de projeto táo gigantesco, Tosi Colombina respondia que nas Índias de Espanha já existiam caminhos como este que interligavam regióes muito mais distantes. ${ }^{16}$

Em 1773, o entáo governador de Goiás, Vasconcelos de Soveral e Carvalho, enviou expedição através do rio Tocantins até a cidade de Belém, a fim de conhecer sua capacidade de navegação e explorar passagens alternativas aos caminhos tradicionais. ${ }^{17}$ Tempos depois, acatando decisão de Lisboa, que estimulava a navegaçáo regular no rio Tocantins, chegava a Vila Boa, em 1782, uma expediçáo enviada pelo governo do Pará. Nove anos depois, o governador Tristáo da Cunha Meneses organiza uma expedição sob o comando do capitáo Tomaz de Souza Vila Real, que desce o rio Araguaia, através do rio do Peixe, partindo do arraial de Santa Rita até Belém do Pará. Na sequência, em 1804, o governador João

\footnotetext{
${ }^{11}$ AHG. Cartas à Corte, 1771, fl. 1.

${ }^{12}$ Ver as descriçôes do austríaco Emmanuel Pohl em POHL, Johann E. Viagem no interior do Brasil. Rio de Janeiro: INL, 1951.v. 1.

${ }^{13}$ PALACIN, Luis. O século do ouro em Goiás, 1722-1822: estrutura e conjuntura numa capitania de minas. Goiânia: PUC Goiás, 2001. p. 136.

${ }^{14}$ Ver, por exemplo, o roteiro de viagem de José da Costa Diogo e João Barbosa desde a derrota do rio São Francisco, através do rio Urucuya, até as minas de Goiás, escrito em 1734, ou a descrição da derrota do rio Tocantins até Belém do Pará, de 1735. Respectivamente, AHU. ACL, CU, Série 008, Cx. 1, D. 8 e AHU. ACL, CU, Série 008, Cx. 1, D. 12.

${ }^{15}$ AHU. ACL, CU, Série 008, Cx. 6, D. 457.

${ }^{16}$ PALACIN, Luis. O século do ouro em Goiás, op. cit. p. 138.

${ }^{17}$ AHU. ACL, CU, Série 008, Cx. 27, D. 1752.
} 
Manoel de Meneses chega a Goiás através do porto de Santa Rita, dirigindo-se à Vila Boa, de onde escreve a Rodrigo de Sousa Coutinho, então secretário da Marinha e Ultramar, enviando uma descrição do roteiro da cidade do Pará até o porto de Santa Rita. ${ }^{18}$

Desta forma, o argumento da distância instigava discursos e projetos, estimulando a criatividade para a solução dos problemas. Quando, em 1749, o ouvidor-geral de Goiás, Agostinho Luís Ribeiro Vieira, relatava ao rei de Portugal as dificuldades de se remeter criminosos para os degredos, "devido às grandes distâncias entre a dita capitania e os portos do mar", apresentava uma alternativa ao problema: propunha que se praticasse em Goiás o que se costumava fazer em Vila Rica de Ouro Preto, conduzindo os criminosos sob a responsabilidade dos mesmos cabos que faziam a escolta do quinto recolhido na capitania. ${ }^{19}$ No mesmo sentido, o então superintendente-geral das minas, Gregório Dias da Silva, solicita, ainda em 1735, a ampliação de sua jurisdição para conhecer os "agravos da Coroa", equiparando-a à dos ouvidores das comarcas. Dias da Silva fundamenta sua argumentação na grande distância que separa as minas de Goiás da "Rellação do Estado", na Bahia. Seu argumento é acolhido pelo Conselho Ultramarino, levando o monarca a autorizar a ampliação de sua jurisdição. ${ }^{20}$

A criatividade ante os obstáculos interpostos pela distância favorecia a instalação de órgãos de controle coloniais, como é o caso da criação da própria capitania. Ainda em 1736, quando o rei João V decidiu ordenar a criação da primeira vila em Goiás, aventou a possibilidade da instalaçấo de uma capitania autônoma. Em setembro de 1739, o governador Luís de Mascarenhas, em resposta à provisão real de 1736, escrevia ao rei de Portugal sobre a necessidade de Goiás ter seu próprio governo, devido à "grande distância" entre São Paulo e as minas de Goiás. ${ }^{21}$

Contudo, além das distâncias entre Goiás, Lisboa e os portos atlânticos da América, uma terceira dimensão na geopolítica do império condicionava as estratégias associadas aos projetos de Lisboa: os espaços interiores das minas. No limite, o alcance das circunscriçốes das diversas instituiçôes da monarquia, as fronteiras entre os diversos poderes e a implantaçáo dos mecanismos de administraçáo e justiça estavam ancorados numa forma de governar indissociável das imposiçôes ditadas pelas distâncias.

Apenas a título de exemplo, vale a pena observar a impressão deixada pelo secretário de governo, Ângelo dos Santos Cardoso, quando descreve, em 1755, a evolução territorial de Goiás, comparando sua extensão com os territórios dos reinos de Portugal e Castela.

(...) e no decurso dos annos que se seguirão, diz ele, se foy estendendo o descobrimento da Comarca; e formando-se arrayaes, onde achavão minas com conveniencia, e se vê hoje tão dilatada, ainda que com os limites incertos, que comprehende muito mais extenção de Paiz, do que na Europa os dois Reinos de Portugal e Castela; pois a sua latitude em calculo mais provavel, excede o de trezentas legoas, e de longitude mais de duzentas, isso se entende em linha recta, pela estimativa dos grãos. ${ }^{22}$

Seguindo esta tendência, marcada pelo sentimento e pelos efeitos das distâncias, o superintendente-geral, Agostinho Pacheco Telles, demonstra, em 1738, a necessidade da implantação de Julgados ${ }^{23}$ nas minas de Goiás, alegando que seus habitantes careciam da aplicação adequada da justiça, devido

\footnotetext{
${ }^{18}$ AHU. ACL, CU, Série 008, Cx. 41, D. 2518.

${ }^{19}$ AHU. ACL, CU, Série 008, Cx. 5, D. 424.

${ }^{20}$ AHU. ACL, CU, Série 008, Cx. 1, D. 38.

${ }^{21}$ AHU. ACL, CU, Série 008, Cx. 1, D. 68.

${ }^{22}$ AHU. ACL, CU, Série 008, Cx. 12, D. 740.

${ }^{23}$ Os julgados são constituídos por territórios sob a jurisdição de um único juiz ordinário de primeira instância, com autonomia judiciária parcial e sem autonomia administrativa. FONSECA, Cláudia Damasceno. Des terres aux villles de l'or. Pouvoir et territoires urbains au Minas Gerais (Brésil, XVIIIe siècle). Paris: Centre Culturel Calouste Gulbenkian, 2003. p. 202-203.
} 
à "distancia" que ficam umas "povoaçôes das outras", sendo preciso "andar trezentas legoas por caminhos dezertos" para atender toda a região. ${ }^{24}$

$\mathrm{Na}$ mesma direção, o governador de São Paulo, Luis de Mascarenhas, informava ao monarca, em setembro de 1739, sobre a importância das minas recém-descobertas de São Luís (Natividade) e no rio Manuel Álvares e a necessidade de se criar uma nova Intendência nas proximidades dos descobertos situados na região norte, devido à "grande distância" entre aquelas minas e a Intendência situada em Vila Boa. ${ }^{25}$

Ao primeiro governador de Goiás não passou despercebida a relação entre o argumento da distância e os avanços institucionais dos projetos de Lisboa. Em ofício ao secretário de Estado da Marinha e Ultramar, Marcos de Noronha instrui a Coroa acerca da necessidade de se estabelecerem não apenas uma, mas duas Casas de Fundição, devido aos rios caudalosos, os índios inimigos, a manutenção do comércio com a Bahia e a grande extensão da capitania. ${ }^{26}$ De olho no "perigo" do contrabando, a Coroa cria a primeira Casa de Fundição em 1752, em Vila Boa e, dois anos depois, uma Intendência e uma segunda Casa de Fundição no arraial de Sáo Félix. ${ }^{27}$

Mesmo com as duas Casas de Fundição em funcionamento, em 1766, o ouvidor-geral de Goiás, Antônio José de Araújo e Sousa, insistia acerca da necessidade de se repartir a capitania em duas comarcas, propondo como marco divisório o rio Maranhão. $\mathrm{Na}$ lista de seus argumentos constavam as dificuldades para a aplicação da justiça e a fundição do ouro, a distância de Vila Boa ao Rio de Janeiro e Bahia e a grande extensão da capitania de Goiás. ${ }^{28}$ Uma segunda comarca, denominada São João das Duas Barras, foi criada no norte da capitania, mas apenas na primeira década do século XIX. ${ }^{29}$

Esta sensação associada às distâncias atravessou o século XVIII, incorporando-se nos discursos das autoridades coloniais. Em 1780, o governador Luís da Cunha Meneses informava à rainha, Maria I, sobre as grandes dificuldades vividas pelos habitantes de Goiás. ${ }^{30}$ Antes de discorrer sobre os inúmeros problemas existentes, acusou, dentre as prioridades que estabelecia para o bom andamento dos projetos de Lisboa, a grande extensão da capitania e sua natureza inóspita como primeiro fator em sua lista de incômodos. ${ }^{31}$

Findo o século XVIII, o governador Francisco de Assis Mascarenhas escreve ao príncipe regente anunciando as vantagens das relaçôes comerciais com o Pará e os grandes recursos existentes na capitania de Goiás. Ressalta a importância do açúcar que poderia fazer frente às exportaçóes para Lisboa, destaca a produção do algodão, que considera o melhor da América, e indica alternativas que poderiam incrementar o comércio local. Contudo, quando se refere ao estado geral da capitania, tendo em mente, provavelmente, o declínio da economia centrada na produção do ouro, associa a "decadência de Goiás" à extensão do território e à falta de pessoas para administrá-la. ${ }^{32}$ Assim, entrado o século XIX, os discursos associados às distâncias tinham ainda muito vigor para justificar as dificuldades encontradas pelo projeto colonial nas minas de Goiás.

Por outro lado, se a extensão da capitania e as distâncias entre os arraiais eram percebidas como obstáculos que deveriam ser transpostos, serviam também para nutrir uma perspectiva diferente acerca

\footnotetext{
${ }^{24}$ AHU. ACL, CU, Série 008, Cx. 3, D. 225.

${ }^{25}$ AHU. ACL, CU, Série 008, Cx. 1, D. 66.

${ }^{26}$ AHU. ACL, CU, Série 008, Cx. 6, D. 475.

${ }^{27}$ SILVA E SOUZA, Luis Antônio da. Memória sobre o descobrimento, governo, população, e cousas mais notáveis da Capitania de Goyaz. In: TELES, José Mendonça. Vida e obra de Silva e Souza. Goiânia: UFG, 1988. p. 71-139, p. 112.

${ }^{28}$ AHU. ACL, CU, Série 008, Cx. 21, D. 1332.

${ }^{29}$ SILVA E SOUZA, Luis Antônio da. Memória sobre o descobrimento, governo, população, e cousas mais notáveis da Capitania de Goyaz, op. cit. p. 103.

${ }^{30}$ AHU. ACL, CU, Série 008, Cx. 32, D. 1999.

${ }^{31}$ Ibidem.

${ }^{32}$ AHU. ACL, CU, Série 008, Cx. 51, D. 2865.
} 
do império português. Lembramos, ainda uma vez, o secretário de governo Santos Cardoso. Logo após comparar a extensáo da capitania aos territórios de Portugal e Castela, afirma que Goiás é um florão de ouro que pertence ao monarca português. Em seguida, numa viagem pelo tempo, lembra a época em que, quando criança, folheava as histórias de Portugal que contavam as glórias da expansão portuguesa, o mais "dilatado e florente patrimônio", "que Deus deo aos nossos monarcas portugueses na Ázia e na África", "que nunca concedeo a soberano algum do universo". Nem mesmo "a antiga soberba imperial de Roma", diz ele, chegou a conhecer, por maior "que fosse o seu poder, o que possuiram os portuguezes naquelas duas partes do mundo". ${ }^{33}$

A descrição das riquezas e da extensão territorial da capitania de Goiás remete as reflexôes de Santos Cardoso à dimensão excepcional do império português construído na Ásia e na África, "reduzido", segundo ele, "à indigência". O que teria diminuído a "grandeza de tanto império", indaga o secretário, "senão os pecados dos vassalos e a dezordem dos ministros"? A tonalidade da comparaçáo presente em suas ponderaçóes revela o temor de que o mesmo destino se reproduza nas dilatadas extensóes dos territórios da América: "Ah", exclama o secretário, "como temo que o mesmo venha a succeder deste [território] Americano, que em suplemento dos outros quazi extintos, Deus sempre atento com os portugueses, ultimamente lhe permitio". ${ }^{34}$

Este salto na interpretação sobre momentos distintos na história do império guarda uma relação direta com o sentimento de distância vivenciado por Santos Cardoso. Neste caso, a distância é sentida como "um conceito espacial que informa e influencia constantemente a análise e a interpretação do mundo": metáfora, fronteira, forma de medir o espaço, que proporciona afastamento ou aproximação. ${ }^{35}$ Nestes termos, conforme o posicionamento de quem olha, a distância filtra as percepçóes da realidade através de um leque de enganos, ilusôes e sobreposiçôes, ${ }^{36}$ que inclui, por outro lado, medos, incertezas e prognósticos futuros. Por esta via, a noção de distância permite penetrar nos meandros dos pensamentos de Santos Cardoso. Do alheamento ou isolamento, enquanto condiçáo provocada pela distância, fazem parte a solidão e o medo. Assim, "o olhar vira-se normalmente para o passado. A distância marca a geografia do espaço perdido, o espaço da infância (...)" ${ }^{37}$ Neste contexto, a distância "obriga a subjetividade à elaboração dum discurso de oposição", "permite uma nova percepção crítica, imanente, conflitual, tanto das circunstâncias presentes quanto do contexto de origem". ${ }^{38}$

Ora, o que inspira no secretário de governo comparaçôes tão amplas e, até mesmo, desproporcionais, senão a sensaçáo que lhe provocam as distâncias que moldam a vida dos habitantes de Goiás? Provavelmente, sentado em sua cadeira, nalgum lugar de Vila Boa, sua posição no tempo e no espaço lhe permitia ver à distância a "indigência" em que se encontrava o império oriental. Porém, visto de perto, após seis anos residindo no "remotíssimo coraçáo destes sertôes", era a necessidade de preservação, provocada por uma percepção crítica do império, que falava mais alto: impunha-se a necessidade de conservar os domínios de Sua Majestade nos distantes sertôes da América.

Assim, a distância imprime um ritmo específico e sedimenta a natureza dos projetos de Lisboa em Goiás, tanto no seu aspecto objetivo (refiro-me aqui às práticas governativas implementadas pela

\footnotetext{
${ }^{33}$ AHU. ACL, CU, Série 008, Cx. 12, D. 740.

${ }^{34}$ Ibidem.

${ }^{35}$ FRANCAVILLA, Roberto. O império visto de longe. A desconstrução do discurso colonial em "Os cus de Judas" de Antônio Lobo Antunes. In: CONGRESSO INTERNACIONAL DA ASSOCIAÇÃO PORTUGUESA DE LITERATURA COMPARADA, IV, 2001, Universidade de Évora. Atas do CIAPLC, Relaçóes intraliterárias, contextos culturais e estudos pós-coloniais. Évora: 2001. Disponível em: <www.eventos.uevora.pt/comparada/volumel.htm>. Acesso em: 26 jan. 2011.

${ }^{36}$ Ibidem.

${ }^{37}$ Ibidem.

${ }^{38}$ Ibidem.
} 
Coroa), quanto no âmbito subjetivo das reflexóes levadas a cabo pelos colaboradores do rei de Portugal. Se os efeitos do alheamento parecem fragilizar os sentimentos e as consciências dos protagonistas em Goiás, impelidos pela busca do ouro, transformam os obstáculos em vetores de suas estratégias, como se os projetos de Lisboa fossem nutridos pela experiência da distância. Como o plasma que envolve o ambiente da sociedade mineradora em suas conexôes com as cidades-portos da América e do reino de Portugal, a distância deve ser conquistada, controlada e, finalmente, vencida.

\section{Intervalos de espera: entre as decisóes do rei e o tempo vivido em Goiás}

Medida de espaço e de tempo, a distância, somada às condiçôes e às limitações técnicas da época, contribuía em muito para definir o ritmo das comunicaçóes. Neste aspecto, apesar da existência de um verdadeiro sistema de comunicação entre Lisboa e Vila Boa, com intenso tráfego de correspondências oficiais, de forte efeito político e administrativo, não era raro que as autoridades coloniais reclamassem da falta de notícias da Corte.

Por exemplo, em 25 de junho de 1767, Joaquim Pedro de Campos, escrivão da Intendência da Casa de Fundiçáo de Vila Boa, escreve a Francisco Xavier de Mendonça Furtado, dando conta dos assuntos pertinentes ao governo das minas e à situação política e econômica de Goiás. No preâmbulo da carta, reclama da falta de notícias da Corte e deixa entrever certa ansiedade gerada pela espera de correspondências provenientes de Lisboa. "A grande demora que tem havido de nau do Reino", diz ele, "nos constitui mais dezejosos de sabermos notícias da corte". Envolto pelo manto da distância, complementa: "pois esta é a única conçolação que experimenta quem vive em táo remotas regioens". 39

Na mesma semana, uma carta do governador João Manoel de Melo ao mesmo secretário de Estado da Marinha e Ultramar confirma que a ausência prolongada de informaçôes vindas de Portugal é motivo de inquietaçóes nas autoridades coloniais. Logo na primeira frase de sua missiva o governador apressa-se em notar a falta de correspondências vindas de Lisboa: "Há mais de seis meses que nos faltam noticias dessa Corte". ${ }^{40}$ Contudo, para alegria de Manoel de Melo, uma nau de guerra que aportou no Rio de Janeiro trazia uma carta de Mendonça Furtado atualizando-o sobre os acontecimentos do Reino. "Unico alívio", reclama, para quem experimenta "tão dilatada ausência." ${ }^{\prime 11}$ Anos depois, em 1776, o governador Soveral e Carvalho queixava-se ao marquês de Pombal sobre a falta de correspondências vindas da Corte, revelando muita insatisfação e apontando como causa para a demora das cartas o descuido dos oficiais responsáveis pelo seu envio. ${ }^{42}$

Descuidos à parte, cartas pessoais e documentos oficiais tinham sempre um longo caminho a percorrer. De Lisboa a Vila Boa, se a tecnologia empregada nos meios de transportes disponíveis à época tornava lentos e inseguros os sistemas de comunicação, as distâncias implacáveis funcionavam como obstáculos que condicionavam ainda mais o ritmo das informaçôes em ambos os lados do Atlântico. As correspondências administrativas de Lisboa para Vila Boa e vice-versa, considerando o tempo adequado às correntes marítimas do Atlântico, bem como ao clima e às monçôes no continente americano, levavam, na melhor das hipóteses, três meses para atingir seus destinos. Se considerarmos o tempo de envio de uma correspondência e o retorno da respectiva resposta, temos, no mínimo, seis meses, na melhor das condiçóes imaginadas, entre, por exemplo, um pleito e seu resultado final. Isso se não computarmos o tempo necessário para análises e pareceres, caso se trate de um procedimento administrativo

\footnotetext{
${ }^{39}$ AHU. ACL, CU, Série 008, Cx. 23, D. 1457.

${ }^{40}$ AHU. ACL, CU, Série 008, Cx. 23, D. 1459.

${ }^{41}$ Ibidem.

${ }^{42}$ AHU. ACL, CU, Série 008, Cx. 28, D. 1841.
} 
ou judicial que envolva uma decisão do rei de Portugal. Neste caso, a tramitação entre os conselheiros do rei e o Paço Real podia demandar alguns meses, de forma que náo era raro que a resposta a uma demanda demorasse mais de um ano para chegar a Vila Boa. "Durante este tempo", como lembra Laurent Vidal, "a vida se instala numa espécie de 'entre-dois' onde cada protagonista deve fazer face à incerteza, à espera de uma decisão distante, tanto desejada quanto temida". 43

Assim, as grandes distâncias geográficas acabam por definir o ritmo das decisóes que embalam os projetos de Lisboa: a gestáo do governo colonial se estabelece nas minas de Goiás a partir de intermináveis intervalos de espera. Sáo dias, semanas, meses e, eventualmente, anos que se devem esperar por uma autorização, uma confirmação, uma notícia, uma informação. Noutras palavras, em Goiás a vida é entrecortada por um permanente tempo de espera.

Portanto, nos espaços de cruzamento entre o ritmo dos projetos da Coroa e a cadência do tempo presente na sociedade mineradora - plasma e lugar da experiência vivida nas minas de Goiás - um tempo muito particular condiciona a natureza das relaçóes coloniais: a temporalidade da espera. Assim, o entendimento proposto a partir dos momentos de espera nos convida a um empreendimento pontual: penetrar nos interstícios, nas frestas e nas fissuras dos diferentes tempos e ritmos da história, que se desdobram a partir de situaçóes inesperadas, marcadas pela incerteza. Por este caminho, nos intervalos entre as decisóes que condicionam o mundo social e político de Goiás, se instalam longos momentos de espera. Assim, a temporalidade da espera cimenta a construção das relaçôes de força e poder, como amálgama que reordena os interesses de Lisboa, adaptando-os às condiçôes locais.

A consciência desta temporalidade específica da espera tem implicaçôes mais amplas para a historiografia de Goiás. Em primeiro lugar, períodos prolongados de espera, associados às incertezas dos acontecimentos, às limitaçóes técnicas da época, aos efeitos da distância e ao caráter violento e instável das relaçóes coloniais, induzem ao rompimento com a imagem de uma sociedade submetida e governada exclusivamente por normas exteriores, ditadas por Lisboa. Em segundo lugar - e ao mesmo tempo - , leva a uma ruptura com uma leitura da história colonial de Goiás que reduz as possibilidades dos protagonistas locais à simples expressão de uma adesão ou recusa às normas impostas pela Coroa. Isso porque os constrangimentos e os limites impostos à capacidade de escolha dos indivíduos não são dados ou controlados mecanicamente, já que são essencialmente inscritos nas relaçóes de força que mantêm entre si. Situam-se, portanto, "no interior" de uma "rede de obrigaçôes, de esperas, de reciprocidades que caracterizam a vida social". ${ }^{44}$

Além disso, os intervalos de espera, espaços intersticiais e transitórios, momentos de incerteza eventualmente sacudidos pela força de eventos não anunciados que surpreendem a vida quotidiana e alteram o ritmo dos acontecimentos, não constituem, necessariamente, tempos de imobilidade. Podem também ser revestidos de grande mobilidade, aflorando à superfície da história como momentos de precipitação. ${ }^{45}$ Assim, a temporalidade da espera, em função da ação criativa e oportuna dos atores - que rompem, eventualmente, com as normas ditadas por Lisboa —, aparece como uma barreira à aplicação mecânica das intençôes e vontades da Coroa. Deste modo, nos convida a lançar outro olhar sobre as práticas sociais e as relaçóes de força e poder nas minas de Goiás. Um convite para observarmos — atentos à multiplicidade dos tempos e dos ritmos sociais — os núcleos urbanos, os centros de mineração e as

\footnotetext{
${ }^{43}$ VIDAL, Laurent. Sous le masque du colonial — Naissances et "décadence” d'une vila dans le Brésil moderne: Vila Boa de Goiás au XVIIIe siècle. Annales Histoire, Sciences Sociales, Paris, n. 3, p. 577-606, mai/juin 2007. p. 578. (Tradução do autor).

${ }^{44}$ CERUTTI, Simona. Processus et expérience: individus, groupes et identités à Turin, au XVIIe siècle. In: REVEL, Jacques (Org.). Jeux d'échelles: la micro-analyse à l'expérience. Paris: Gallimard; Le Seuil, 1996. p. 175. (Tradução do autor).

${ }^{45}$ VIDAL, Laurent. Mazagão: la ville que traversa l'Atlantique — du Maroc à l'Amazonie (1769-1783). Paris: Flammarion, 2005. p. 254.
} 
relaçóes de força que lhes correspondem como espaços e circuitos de espera. Como nos exorta Laurent Vidal, a propósito de uma sociologia da espera nos espaços urbanos coloniais, "Observar a cidade como um espaço de espera" incita o observador "a ler de outras formas suas potencialidades, a repensar suas centralidades, a redefinir o desejo de cidade". ${ }^{46}$

Assim, os gestos que dão forma à sociedade e às relaçôes de força e poder em Goiás configuram uma espécie de "cenografia da espera" ${ }^{47}$ Dito de outra forma, os cenários dos episódios que envolvem a intrincada rede de interesses e relacionamentos entre os protagonistas políticos em Goiás são amalgamados por intervalos consideráveis de espera, definidos pela perspectiva e pela cadência das demandas locais e respectivas respostas elaboradas em Lisboa. Na prática, o curso ordinário dos acontecimentos impunha ao ritmo das açóes da Coroa longos momentos de espera: no interior distante dos sertóes, intervalos de tempo descontínuos se interpóem entre as decisões tomadas em Lisboa e sua aplicação imediata. Deste modo, a espera é reconhecida e sentida pelos atores e protagonistas como fatalidade que condiciona o ritmo da própria existência, que define e/ou redefine a intensidade das relaçôes nas minas de Goiás.

Não raro, as expectativas da Coroa, tanto quanto dos protagonistas locais, são entrecortadas pela apreensão e indefinição nos contextos e ambientes de espera. $\mathrm{Na}$ dissonância entre o ritmo das decisóes da Coroa e a cadência dos acontecimentos no tempo vivido da sociedade mineradora, a temporalidade da espera mergulha os homens numa duração intermediária, num entre-deux, que condiciona suas experiências. Os momentos e intervalos de espera pelas decisões do rei de Portugal dão forma e conteúdo às palavras de Roland Barthes, colocando em suspensão os cenários e a vida dos súditos no coração da América portuguesa: a prerrogativa de todo poder é fazer esperar. ${ }^{48}$

\section{A espera como estratégia e ação: a morte de João Manoel de Melo} e o governo provisório de 1770

Todavia, somados às expectativas geradas pelas situaçôes de espera, acontecimentos náo anunciados provocam rachaduras no tecido social, produzindo espaços vazios de poder e ocasióes que rompem o curso natural dos acontecimentos. A morte, por exemplo, surpreende os homens e altera o funcionamento normal das instituiçóes, constituindo momentos de precipitação que antecipam estratégias imprevisíveis, induzindo a mutações e inversōes nas relaçôes de força e poder. São períodos de espera que propiciam iniciativas incomuns na mecânica das lutas e no jogo singular da dominação colonial.

Em Goiás, o desaparecimento súbito do governador João Manoel de Melo, governador entre 1759 e 1770, provoca uma interrupçáo no curso ordinário dos acontecimentos. Introduzindo um estado de exceção à normalidade política, sua morte dá lugar à constituição de um governo provisório, capitaneado pelo Senado da Câmara.

Por suas especificidades, a descrição do caso da morte de João Manoel de Melo desnuda a experiência dos protagonistas em Goiás num momento de exceção. Período de ruptura momentânea com as normas, que caracteriza um caso singular, revelando a consciência dos atores num momento intermediário, de transição. Assim, o lapso de tempo entre a morte de Manoel de Melo, a nomeação e a chegada de um substituto, constituía a ocasião para uma ação contundente que conduziria ao cargo de maior importância da capitania os grupos políticos locais. Enquanto esperavam por uma decisão do monarca, conscientes do intervalo de tempo do qual dispunham, moviam-se por entre as brechas, nos espaços

\footnotetext{
${ }^{46}$ Ibidem, p. 255. (Tradução do autor).

${ }^{47}$ BARTHES, Roland. Fragments d'un discours amoureux. Paris: Seuil, 1977. p. 47. (Tradução do autor).

${ }^{48}$ Ibidem, p. 50.
} 
intermediários da espera, preenchendo o vazio de poder deixado pela morte do principal representante da Coroa.

Acometido de uma apoplexia, ${ }^{49}$ a morte do capitão-general Joáo Manoel de Melo teria deixado, nas palavras de Pereira de Alencastre, a administraçấo em acelafia. ${ }^{50}$ Ato contínuo, no dia seguinte às exéquias do governador, foram convocados à sede do Senado da Câmara "todos os homens bons da governança, oficiais militares pagos, auxiliares, e da ordenança”. Até que o rei de Portugal fosse informado e tomasse as providências cabíveis, tinham por objetivo a adoção urgente de estratégias que evitassem uma interrupção abrupta na administração da capitania. ${ }^{51}$ Reunidos o ouvidor de Goiás, dois juízes ordinários, quatro vereadores, o procurador do Senado da Câmara e outras autoridades constituídas em Vila Boa, num total de 46 pessoas, elegeram uma junta provisória de governo. Como consta no Auto de Posse dos eleitos, foram aclamados para o cargo de governador o ex-juiz de fora da cidade de Salvador e então ouvidor-geral e corregedor da comarca, Antônio José Cabral de Almeida, ${ }^{52}$ o sargento-mor da cavalaria auxiliar paga, Antônio Thomas da Costa, e o capitáo da Companhia de Dragóes, Damiáo José de Sá Pereira. ${ }^{53}$

Empossados os membros do governo provisório, no dia 15 de março de 1770, os oficiais da Câmara escreviam ao rei José I avisando-o do falecimento do governador e informando a respeito das medidas adotadas para a eleição da junta provisória. Em anexo, enviam cópia da ata da eleição e do Auto de Posse dos eleitos, registrados no Livro das Vereanças do Senado da Câmara. ${ }^{54} \mathrm{Na}$ carta, reconhecem a importância do cargo de governador, "lugar-tenente de Vossa Magestade neste país", e justificam a urgência da indicação dos governadores interinos. Ao final da missiva, afirmam acreditar que a iniciativa do Senado da Câmara de Vila Boa tenha sido do agrado do rei de Portugal.

Por sua vez, no dia 16 de março, são os próprios integrantes do governo provisório que comunicam ao monarca acerca da eleição, solicitando informaçôes quanto às medidas necessárias para o provimento do cargo de governador. Além disso, afirmam ter assumido o governo de Goiás "em nome de Vossa Magestade", com a única intenção de preservar a tranquilidade e a "felicidade" "dos povos". Reafirmam, ainda, que a finalidade da iniciativa seria a de servir exclusivamente aos interesses do monarca, evitando qualquer tipo de alteração na capitania, contribuindo para que os vassalos do rei continuassem a dispensar a tão necessária obediência à Coroa..$^{55}$

Além de informar ao rei, relatam os mesmos acontecimentos ao secretário dos Negócios Estrangeiros ${ }^{56}$ e ao secretário da Marinha e Ultramar, ${ }^{57}$ solicitando providências por parte de Lisboa. Entre os dias 16 e 23 de março, várias correspondências foram remetidas de Vila Boa para Lisboa, dando conta dos mesmos acontecimentos. ${ }^{58}$ Embora não tenha sido possível identificar as respostas emitidas

\footnotetext{
${ }^{49}$ Afecção cerebral (derrame sanguíneo ou seroso) acompanhada de privação dos sentidos e dos movimentos. No caso de João Manoel de Melo, o ataque que o acometeu foi fulminante. Tendo sentido os primeiros sintomas por volta das oito horas e trinta minutos, faleceu às três horas e meia da tarde do dia 13 de março de 1770. AHU. ACL, CU, Série 008, Cx. 25, D. 1586 e AHU. ACL, CU, Série 008, Cx. 25, D. 1587.

${ }^{50}$ ALENCASTRE, José Martins Pereira de. Anais da Provincia de Goiás (1863). Goiânia: Governo de Goiás, 1979. p. 170.

${ }^{51}$ AHU. ACL, CU, Série 008, Cx. 25, D. 1587.

${ }^{52}$ AHU. ACL, CU, Série 008, Cx. 25, D. 1620.

${ }^{53}$ AHU. ACL, CU, Série 008, Cx. 25, D. 1585.

${ }^{54}$ Ibidem.

${ }^{55}$ AHU. ACL, CU, Série 008, Cx. 25, D. 1587.

${ }^{56}$ AHU. ACL, CU, Série 008, Cx. 25, D. 1588.

${ }^{57}$ AHU. ACL, CU, Série 008, Cx. 25, D. 1589.

${ }^{58}$ Do ouvidor-geral ao secretário dos Negócios Estrangeiros (AHU. ACL, CU, Série 008, Cx. 25, D. 1590) e ao secretário da Marinha e Ultramar (AHU. ACL, CU, Série 008, Cx. 25, D. 1591); do secretário do governo da capitania de Goiás ao secretário da Marinha e Ultramar (AHU. ACL, CU, Série 008, Cx. 25, D. 1592); do sargento-mor do Regimento da Cavalaria Auxiliar ao secretário de Negócios Estrangeiros (AHU. ACL, CU, Série 008, Cx. 25, D. 1593) e ao secretário da Marinha e Ultramar (AHU. ACL, CU, Série 008, Cx. 25, D. 1594); do escrivão da Intendência e Casa de Fundição ao
} 
por Lisboa, um ofício da Junta Provisória dirigido a Luís de Almeida, segundo marquês de Lavradio e vice-rei do Estado do Brasil, obteve resposta incisiva e contundente.

Indicando o recebimento da carta dos governadores interinos, o vice-rei do Brasil acusava-os, em carta-resposta de maio de $1770,{ }^{59}$ de não terem pedido sua aprovação, qualificando de arbitrária e intempestiva a eleição da Junta Provisória. Para fazê-lo, afirma Luís de Almeida, seriam necessárias ordens do próprio rei de Portugal. Portanto, seu julgamento sobre o governo provisório é peremptório: deveria ser objeto de severa repreensão, de nenhum efeito e validade. De acordo com Luís de Almeida, as autoridades de Vila Boa deveriam ter esperado por uma resolução do monarca, permanecendo nos limites conferidos por suas próprias jurisdiçôes. Ante tais circunstâncias, nomeou imediatamente um governador interino (Antônio Carlos Furtado de Mendonça) e determinou que a capitania ficasse sem governo até sua chegada a Vila Boa. Ordenou, sobretudo, que os integrantes da Junta Provisória eleitos de forma inconveniente e inadequada — se abstivessem de exercer as funçóes destinadas somente aos governadores.

Contudo, as repreensóes provenientes do Rio de Janeiro não ficaram sem resposta. O ouvidor-geral e membro do governo provisório, Antônio José Cabral de Almeida, em ofício dirigido ao secretário da Marinha e Ultramar, Francisco Xavier de Mendonça Furtado, justifica os motivos de sua participação e argumenta acerca do fato de ter o vice-rei estranhado a formação da Junta Governativa em Goiás. ${ }^{60}$

Instrumentalizando sua argumentaçáo, o ouvidor-geral alega que a ausência do governador poderia provocar uma paralisia administrativa, já que muitas de suas responsabilidades cotidianas, próprias e privativas do cargo, seriam retardadas, prejudicando os interesses do monarca na capitania. Relacionando de forma lógica uma série de motivos e demonstrando preocupação quanto aos negócios régios nas minas de Goiás, seu discurso visava, sobretudo, atenuar eventuais medidas punitivas por parte da Coroa.

Em primeiro lugar, Cabral de Almeida afirma que sendo a inspeção da Real Fazenda e das Casas das Intendências de responsabilidade do governador, ninguém mais poderia inspecioná-las, o que traria grande prejuízo aos cofres da Coroa. Em função da falta de portarias emitidas pelo governador, o funcionamento dos Registros também ficaria comprometido, paralisando as transaçóes comerciais. Mais grave ainda, a remessa anual do quinto ficaria adiada para o próximo ano em funçáo do início da estação chuvosa. Além disso, cada uma das Casas de Fundição (a de Vila Boa e a de São Félix) possuía quatro fiscais, eleitos pelo Senado da Câmara e aprovados pelo ouvidor, mas providos nos seus cargos, a cada três meses, pelo governador. Como os fiscais antigos tinham seu tempo de serviço limitado pelo respectivo Regimento, sem o provimento do governador os novos fiscais não poderiam ser empossados nas Casas de Fundição.

Advertia ainda que, exatamente no dia da eleição da Junta de Governo, chegaram os quintos da Casa de Fundição de Sáo Félix, bem como a remessa de relação dos mapas que, somados aos de Vila Boa, não haveria quem os conferisse, nem tampouco se poderia remetê-los ao Rio de Janeiro, sem a anuência do governador. Além do mais, o ouvidor Cabral de Almeida fez questáo de lembrar que — ainda "semivivo o governador" - existiam pesadas discórdias entre o capitão da companhia dos Dragóes, Damião José de Sá Pereira, e o sargento-mor de Auxiliares, arrogando para si o governo da capitania. Neste aspecto, a eleição dos governadores provisórios teria funcionado como o melhor meio encontrado para pacificar os ânimos. Além disso, como o comando militar da capitania estava submetido à autoridade exclusiva do governador e capitão-general, alguns problemas urgentes envolvendo as forças militares (em luta permanente contra os índios caiapós) colocavam em risco a segurança da população dos arredores de Vila Boa.

secretário da Marinha e Ultramar (AHU. ACL, CU, Série 008, Cx. 25, D. 1596); do administrador da casa do governo de Goiás ao secretário da Marinha e Ultramar (AHU. ACL, CU, Série 008, Cx. 25, D. 1597).

${ }^{59}$ Carta publicada na íntegra em ALENCASTRE, José Martins Pereira de. Anais da Província de Goiás (1863), op. cit. p. 171.

${ }^{60}$ AHU. ACL, CU, Série 008, Cx. 25, D. 1605. 
Em resumo, a eleição do governo provisório teria o mérito de evitar inúmeros inconvenientes, funcionando, nas palavras do ouvidor, como um "interino remédio". Desta forma, unidos em benefício dos interesses de Lisboa, poderiam fazer "o que a cada hum em particular não podia competir". Além do mais, na opiniáo do ouvidor-geral, "não se tratou de hum governo absoluto", mas, ao contrário, de uma Junta Provisória que pudesse suprir algumas deficiências tocantes à administração da capitania. ${ }^{61}$

Ainda de acordo com o ouvidor, os três membros eleitos teriam participado do governo provisório movidos, exclusivamente, pelo senso de responsabilidade. Nestas circunstâncias, uma atitude passiva poderia pôr em xeque não apenas o quotidiano dos habitantes, mas, sobretudo, os soberanos interesses de Lisboa. Estavam em jogo, portanto, a situaçáo econômica e militar da capitania, a segurança da populaçáo e a manutenção da ordem política, que ameaçava, inclusive, a estabilidade e o equilíbrio dos poderes locais. Enquanto vassalos comprometidos com o projeto de Lisboa náo poderiam faltar no cumprimento do dever para com o rei de Portugal, pois, "suposto falecesse o governador não falecia governo". ${ }^{62}$

Finalmente, defendendo-se das acusaçóes do vice-rei do Brasil, Cabral de Almeida afirma com todas as letras que, ainda que digam que o método utilizado não tenha sido o mais adequado, não houve malícia em seus propósitos. Diante disso, confiava que seria poupado dos castigos que porventura houvessem contra as pessoas que participaram do arranjo orquestrado para a sucessão do governador João Manoel de Melo.

De sua parte, as determinaçóes do vice-rei — que em tese seria a autoridade suprema na colônia apontam, na prática, para o exercício de uma supremacia limitada. Mesmo assim, as ordens emanadas de sua carta foram objeto de grande desconforto. De acordo com Pereira de Alencastre, "A íntegra desta carta produziu em Vila Boa sério descontentamento". Parecia incompreensível ignorar o vazio no governo de uma "capitania tão remota". Segundo ele, a severa repreensão do vice-rei contra a eleição do "triunvirato" causou uma impressão muito desagradável, já que o "fato que sucedia em Goiás não era novo no Estado do Brasil; já se tinha dado em Pernambuco e Bahia”. ${ }^{63}$

O governador interino, Furtado de Mendonça, assume o governo de Goiás no dia 17 de agosto de 1770 e desarticula, imediatamente, a Junta Provisória. ${ }^{64}$ Dissolvido o governo provisório, o novo governador tenta restabelecer o curso normal da vida administrativa na capitania, mas se depara com a resistência do capitão da Companhia dos Dragóes, Sá Pereira, que, além de ridicularizar as determinaçôes do vice-rei, tentou resistir às ordens expedidas pelo governador. De pronto, Furtado de Mendonça abre um "sumário de averiguaçôes" contra o capitão dos Dragões, determinando sua prisão. ${ }^{65}$ Sua história pregressa, recheada pelas descriçôes de algumas testemunhas elencadas nos autos, garantiu a Sá Pereira a imagem de um homem insolente e dado a violências, permitindo ao governador interino desqualificar suas atitudes e pondo fim ao caso.

Menos de um mês após a chegada de Furtado de Mendonça, um decreto do monarca nomeava José de Almeida Vasconcelos de Soveral e Carvalho para o cargo de governador de Goiás. ${ }^{66}$ Mesmo assim, o governador interino permaneceu em Goiás até agosto de $1772 .{ }^{67}$ Além da prisão do capitão da Companhia dos Dragóes, não houve nenhuma condenação por parte da Coroa contra os envolvidos na eleição da Junta de Governo de $1770 .{ }^{68}$

\footnotetext{
${ }^{61}$ Ibidem.

${ }^{62}$ Ibidem.

${ }^{63}$ ALENCASTRE, José Martins Pereira de. Anais da Provincia de Goiás (1863), op. cit. p. 171.

${ }^{64}$ AHU. ACL, CU, Série 008, Cx. 25, D. 1613.

${ }^{65}$ AHU. ACL, CU, Série 008, Cx. 25, D. 1631.

${ }^{66}$ AHU. ACL, CU, Série 008, Cx. 25, D. 1616.

${ }^{67}$ AHU. ACL, CU, Série 008, Cx. 26, D. 1683.

${ }^{68}$ ALENCASTRE, José Martins Pereira de. Anais da Provincia de Goiás (1863), op. cit. p. 172.
} 
A natureza excepcional do acontecimento: a temporalidade da espera como matéria da vida social no tempo presente

Nesta narrativa, os efeitos das distâncias entre Vila Boa, o Rio de Janeiro e Lisboa aparecem como elementos específicos, que tingem de forma peculiar o quadro dos acontecimentos em Goiás. As "distâncias de tempo" abrem fissuras nas quais os grupos políticos encontram ocasiōes "para garimpar alguns inesperados benefícios". Desde logo, é "necessário entender a distância enquanto relação social" ${ }^{69}$ Neste aspecto, o tempo social, político e administrativo em Vila Boa dependia do ritmo das providências tomadas ora na capital do vice-reino, ora na capital do império. Além disso, uma rede burocrática de funcionamento lento e confuso estimulava o improviso, criando um clima favorável às decisóes marcadas pelo imediatismo. Assim, conscientes das restriçôes inerentes às suas atribuições, membros da elite de Vila Boa arriscaram-se num arrojado jogo de forças, ocupando o "lugar-tenente" do rei no governo da capitania.

A partir das possibilidades oferecidas por um estudo de caso, ${ }^{70}$ a narrativa destes acontecimentos parece-nos pertinente para elucidar a experiência dos atores no interior de um evento que, noutras circunstâncias, teria assumido os contornos de uma longa espera nas minas de Goiás. Em primeiro lugar, é preciso considerar os efeitos imediatos da morte do governador. A sequência de atos improvisados, associados à possibilidade de interrupção do funcionamento habitual dos mecanismos de governo, induz a uma ruptura nas relaçóes quotidianas de poder, cujos espaços institucionais são redefinidos transitoriamente, a partir da ação criativa dos atores e protagonistas em Goiás. Neste sentido, e em segundo lugar, a morte inesperada do governador instaura as condiçóes adequadas para o desdobramento de condutas e atitudes que têm a pretensão de definir noutros termos a relação entre a norma e a exceção. Desta forma, o governo provisório de 1770 põe em questão a prática adotada em todo o império no que diz respeito à substituição dos governadores, em caso de ausência repentina, até então assentada na autoridade exclusiva dos vice-reis. O procedimento adotado em Goiás seguiu um ritual que os costumes tinham tornado método comum, praticado, inclusive, noutras capitanias da América, notadamente na Bahia e no Rio de Janeiro. ${ }^{71}$ Como alega em carta ao rei José I, o Senado da Câmara procedeu à nomeação da Junta de Governo por não ter sido possível encontrar "entre os papéis" do espólio do governador morto as regras ou "as vias de sucessão para o governo". ${ }^{72}$

De fato, a inexistência de uma legislação específica para o caso funcionou como brecha legal e revestiu de legitimidade as decisóes tomadas em Vila Boa de Goiás. Contudo, casos como estes geravam uma situação incômoda para a Coroa, quase sempre insatisfeita com as rupturas provocadas nas hierarquias estabelecidas na administração colonial..$^{73}$ Assim, somada a outros episódios, a morte de Joáo Manoel de Melo acabou precipitando uma iniciativa inovadora da Coroa, nutrida por uma reflexão amadure-

\footnotetext{
${ }^{69}$ Segundo a reflexão proposta por Laurent Vidal, muito cara às intuiçôes que inspiram este artigo, as distâncias de tempo (tema clássico na filosofia) criam tempos de espera, noção fundamental para se entender a importância da duração nos deslocamentos humanos. VIDAL, Laurent. Cidades em espera, sociedades em espera no Brasil — colônia: alguns desafios metodológicos. (Texto inédito).

${ }^{70}$ PASSERON, Jean-Claude; REVEL, Jacques. Penser par cas. Paris: EHESS, 2005.

${ }^{71}$ AHU. ACL, CU, Série 008, Cx. 25, D. 1585.

${ }^{72}$ Ibidem.

${ }^{73}$ Ausências repentinas de governadores não foram raras nas várias regiōes do império, o que proporcionava oportunidades para a composição de governos provisórios nem sempre aprovados por Lisboa. Um exemplo extremo de domínio das elites locais através de governos interinos é o de São Thomé do Príncipe onde, durante dois séculos, as elites da ilha responderam pelo governo local em dez oportunidades. BRILHANTE, Neuma. Nas franjas do império ultramarino português: a experiência insular de São Tomé e Príncipe no despertar dos oitocentos. História, São Paulo, v. 28, n. 1, p. 71-97, 2009.
} 
cida ao longo do tempo: a edição do Alvará de Sucessão, ${ }^{74}$ que estabelecia os mecanismos legais para eventuais substituiçóes dos governadores e capitáes-generais no império, expedido em 12 de dezembro de 1770, logo após o desfecho do caso da Junta Provisória de Goiás.

Em terceiro lugar, não obstante a ocorrência de casos semelhantes noutras partes do império, a Junta Provisória de Goiás preserva sua singularidade, instaurando uma sorte de julgamento ou reflexão que força a atenção por parte de Lisboa, conduzindo a Coroa a adotar novas regras através da aplicação de uma nova legislação. Desde logo, a ausência de uma ordenação específica, a desconfiança entre as diferentes esferas de poder, as suspeitas nutridas por Lisboa quanto à probidade de seus vassalos, a configuração confusa das hierarquias entre as diversas autoridades e a existência de uma cultura da intriga que alimentava os bastidores da vida política do Império constituem elementos que dáo contornos delicados e ao mesmo tempo bombásticos ao caso de Goiás.

Assim, as distâncias que separam Vila Boa de Lisboa e da sede do vice-reino do Brasil ampliam os efeitos destes fenômenos. A lentidão dos sistemas de informaçáa e das correspondências administrativas produz intervalos de espera prolongados, criando vazios que estimulam decisóes transitórias de grandes repercussóes. Momentos breves, provisórios, que fermentam desconfianças, nutrindo, sobre um campo aberto de possibilidades, ambições e interesses que sedimentam as relações de dominação coloniais em Goiás.

De fato, a instalação da Junta Provisória revela, essencialmente, dois aspectos da vida política em Goiás: além de reforçar o sentimento de autonomia em relação aos demais espaços de decisão, o episódio indica a legitimidade do poder das elites de Goiás em face da multiplicidade de poderes no império. Além disso, entre a morte do governador e a chegada de seu sucessor, entre a nomeação, os preparativos para a viagem e a travessia do sertâo, transcorria um intervalo de espera que em Vila Boa assume um significado muito particular: a convivência com uma espécie de défaillance do poder comprometeria, a curto termo, o funcionamento adequado da estrutura governativa planejada por Lisboa. Há um deslocamento, uma margem de indefinição, que arrasta a cidade e suas instituiçôes para uma zona de interregno, que mergulha as motivaçôes dos habitantes numa situação confusa, obscura, ditada por um sentimento de vazio institucional. Neste contexto, as elites políticas locais são incitadas a assumir o poder a fim de assegurar a governabilidade e a continuidade do governo. Ainda que intempestivas aos olhos do vice-rei, é o medo do vazio que marca as decisóes das autoridades em Vila Boa. Semelhantes aos episódios lembrados por Yves-Marie Bercé, estes "momentos inscritos no tempo pelos acasos da história assumem pouco a pouco a imagem de um desvario coletivo". Nessas ocasióes, as hierarquias habituais tendem a desaparecer e os constrangimentos exercidos pelos poderes distantes são interrompidos. Em detrimento das instruçôes e das ordens que recebem e deveriam seguir, as autoridades locais as ignoram ou fingem não escutá-las. Elas "se refugiam na gestão do imediato e do inevitável". ${ }^{75}$ Em meio ao vazio, a autoridade da Coroa se desagrega, as ordens dos representantes do monarca permanecem sem execução.

Surpreendidos pela morte não anunciada, no compasso da espera pelas decisões do rei de Portugal, era preciso ocupar o lugar institucional deixado pela ausência do governador — território institucional vazio que deveria ser ocupado. Desde logo, é preciso reconhecer que as elites de Vila Boa não são indiferentes ao tempo. Sua inquietude e sua consciência do futuro póem em relevo a coincidência entre a ordem dos interesses locais e as necessidades mais amplas dos projetos de Lisboa: morto o governador, como afirmou o ouvidor, que sobreviva o governo. ${ }^{76}$

\footnotetext{
${ }^{74}$ Arquivo Nacional do Rio de Janeiro (ANRJ). Ordem de Sucessão sobre as Pessoas que devem suceder nos Governos, em falta dos Governadores, 12 de dezembro de 1770, Códice 64, v. 17, fls. 34v-36v.

${ }^{75}$ BERCÉ, Yves-Marie. Vide du pouvoir. Nouvelle légitimité. Annales Histoire, Économie et Société, Paris, ano 10, n. 1, p. 23-25,1991. (Tradução do autor).

${ }^{76}$ AHU. ACL, CU, Série 008, Cx. 25, D. 1587.
} 
Conscientes da existência de um longo intervalo de espera que, na prática, funcionava como obstáculo às açóes imediatas das autoridades da Coroa, o tempo em Vila Boa era sentido como uma janela plena de incertezas, aberta a todas as possibilidades. Era preciso, então, antecipar e determinar o futuro. Efetivamente, a missão das elites locais e de suas intervençôes era justamente afastar o vazio, antecipando-se à crise iminente, assegurando a boa continuidade das atividades associadas aos interesses da Coroa. De fato, o que procuram preservar, nesta zona de espera, neste vazio político e institucional cuja gênese está na morte do governador, é a integridade e a unidade dos planos de Lisboa.

Contudo, se a intenção do vice-rei é fazer esperar, deslegitimando as decisôes locais em função do exercício de sua própria autoridade, a espera das elites de Vila Boa guarda, ainda, outro sentido: ela não é ociosa, pois mediada pela ação. Em Goiás, a espera é ativa, pois o tempo é percebido como algo que traz a degradação das atividades coloniais em curso. Neste aspecto, as autoridades locais recusam a passividade, abstendo-se de uma espera passiva, pois existe um tempo, um ritmo exterior que náo corresponde ao tempo interior: o ritmo dos projetos de Lisboa, mediados pelo Rio de Janeiro, é percebido de maneira diferente em Vila Boa. Neste sentido, o tempo não ocorre necessariamente de forma simultânea, contínua ou homogênea entre os espaços coloniais de conquista, pois revela ritmos diferentes, deslocamentos, rupturas, descontinuidades e tensóes.

Portanto, no interior dessas tensôes, a espera em Vila Boa é uma espera ativa: é preciso urdir, tramar. Suas atividades constituem uma sorte de estratagema, pois se trata de ocupar o vazio e aproveitar o tempo disponível para exercer seus poderes, assegurando "a tranquilidade dos povos e tudo aquilo que conduza à sua felicidade" ${ }^{77}$ Assim, a instalação do governo provisório é uma atividade que funciona como uma manobra provisória que, em que pesem as resistências, confirma e torna pública a autonomia e a legitimidade dos poderes das elites de Vila Boa. As composiçóes políticas que resultaram na formaçáo do governo provisório aparecem como o melhor caminho para antecipar uma resposta, preencher o vazio de poder e controlar o tempo de espera.

Finalmente, tanto a morte de Manuel de Melo quanto a Junta Provisória produzem um efeito nada vulgar. O lapso de tempo que separa o desaparecimento do governador e a chegada de seu sucessor é revestido de uma essência muito particular: "Dotado de uma finalidade, ele se descola da cronologia do curso ordinário das coisas e se distingue por um ritmo e uma amplitude próprios" ${ }^{78}$ A partir de sua aparição, a Junta Provisória anuncia-se como um fato inusitado, superando, em peso e importância, o próprio evento da morte do governador, relegando-o ao passado, instrumentalizando-o como pano de fundo para os gestos encenados pelas autoridades de Vila Boa.

Assim, o acontecimento que se desenrola no tempo vivido de Goiás tem efeitos e repercussôes de longo alcance. Sua emergência no tempo é imediatamente partilhada entre todos aqueles que o anunciam, que o veem, que ouvem falar dele, que o fabricam ou a ele se submetem. Distinguido por uma temporalidade específica, multiplica as interaçóes e os confrontos, já que, como lembra Arlette Farge, "para chegar à superfície da história o acontecimento deve ser percebido e caracterizado". "É, provavelmente", diz ela, "a surpresa de vê-lo emergir, a indignaçáo, talvez mesmo o pavor que suscita que o constitui em acontecimento". ${ }^{79}$ Percebido de formas distintas — com surpresa em Lisboa e, certamente, com indignação no Rio de Janeiro - , o governo provisório produz interpretaçóes contraditórias, de acordo com as posiçôes dos atores na hierarquia dos poderes do império. Por outro lado, não há neutralidade nos gestos das autoridades em Vila Boa, nem, tampouco, no discurso pronunciado pelo vice-rei do

\footnotetext{
${ }_{77}$ AHU. ACL, CU, Série 008, Cx. 25, D. 1605.

${ }^{78}$ VIDAL, Laurent. Les larmes de Rio. Paris: Aubier, 2009. p. 142.

${ }^{79}$ FARGE, Arlette. Penser et définir l'événement en histoire. Approche des situations et des acteurs sociaux. Terrain, Paris, n. 38, p. 6, mar. 2002. (Tradução do autor). Disponível em: <http://terrain.revues.org/document1929.html>. Acesso em: 28 jun. 2008.
} 
Brasil. Ao contrário, estão impregnados pelos efeitos do conflito, marcados pelas relaçôes de dominação e submissão, pela multiplicidade de injunçôes em face da ordem social e das "situaçóes econômicas e políticas responsáveis por sua produção". ${ }^{80}$

Este tempo transitório de espera é, sobretudo, objeto de um jogo que tem implicaçóes diretas com as relaçôes de força e poder: diante do risco de imposição do vazio, os acontecimentos que tiveram lugar em Vila Boa denunciam a natureza excepcional do acontecimento. Neste contexto, a temporalidade da espera constitui um aspecto da realidade social, uma duração específica no interior dos tempos múltiplos e contraditórios da história, que não se reveste apenas de meras substâncias do passado, pois compóe também a própria matéria da vida social do tempo presente.

${ }^{80}$ Ibidem, p. 9. 